\title{
Jousmall of Adolescent and Young Adult Oncology
}

Journal Name: http://mc.manuscriptcentral.com/jayao

\section{Antineoplastic agents and (in)fertility: informing patients to improve decisions}

\begin{tabular}{|c|c|}
\hline Journal: & Journal of Adolescent and Young Adult Oncology \\
\hline Manuscript ID & JAYAO-2017-0094.R2 \\
\hline Manuscript Type: & Original Article \\
\hline Date Submitted by the Author: & $n / a$ \\
\hline Complete List of Authors: & $\begin{array}{l}\text { Silva, Cristina; Universidade de Coimbra Faculdade de Farmacia, } \\
\text { Pharmacology Department } \\
\text { Santos, Teresa; Coimbra Hospital and University Centre (CHUC), EPE, } \\
\text { Human Reproduction Department; Faculty of Medicine of the Univerisity of } \\
\text { Coimbra } \\
\text { Melo, Cláudia; Faculty of Psychology and Educational Sciences of the } \\
\text { University of Coimbra; Unit for Psychological Intervention, Maternity Dr. } \\
\text { Daniel de Matos, Coimbra Hospital and University Centre (CHUC), EPE } \\
\text { Ribeiro Rama, Ana Cristina; Centre for 20th Century Interdisciplinary } \\
\text { Studies CEIS20; Universidade de Coimbra Faculdade de Farmacia, } \\
\text { Pharmacology Department }\end{array}$ \\
\hline Keyword: & Infertility, Oncofertility, Supportive Care, Late Effects \\
\hline \multirow[t]{2}{*}{$\begin{array}{r}\text { Manuscript Keywords (Search } \\
\text { Terms): }\end{array}$} & $\begin{array}{l}\text { infertility, oncofertility, decision support, information resources, } \\
\text { chemotherapy adverse effects, fertility preservation }\end{array}$ \\
\hline & $\begin{array}{l}\text { Purpose: Infertility is a potential adverse effect of cancer treatment, and } \\
\text { future fertility is an important issue for cancer patients. In Portugal, the } \\
\text { Centre for Fertility Preservation of CHUC, EPE, conducted a project to } \\
\text { develop and disseminate oncofertility information resources. Here, we } \\
\text { report the results of the specific component of this program, which } \\
\text { intended to produce information resources that promote patients' } \\
\text { awareness of the subject and to support decisions concerning fertility } \\
\text { preservation. } \\
\text { Methods: Guidance for writing health information for patients and criteria } \\
\text { for developing decision aids were gathered. Information needs were } \\
\text { assessed (literature review and locally applied questionnaire). Resources } \\
\text { were pre-tested with a sample of patients and professionals. Their } \\
\text { readability, presentation quality and ability to support decisions were } \\
\text { evaluated. } \\
\text { Results: General information handouts on infertility risk and decision aids } \\
\text { about fertility preservation options were developed and positively } \\
\text { evaluated. The resources are currently being distributed in collaboration } \\
\text { with several national organizations. } \\
\text { Conclusions: Through our multidisciplinary information program, }\end{array}$ \\
\hline
\end{tabular}




\section{Antineoplastic agents and (in)fertility: informing patients to improve decisions}

\section{Running head}

Oncofertility: Informing patients to improve decisions

\section{Authors}

Cristina Silva ${ }^{1}$, Teresa Almeida Santos ${ }^{2,3}$, Cláudia Melo ${ }^{4}$, Ana Cristina Ribeiro Rama ${ }^{1,5}$

\section{Corresponding author}

Cristina Silva ${ }^{1}$

tina.silva@,sapo.pt

Pólo das Ciências da Saúde

Azinhaga de Santa Comba

3000-548 Coimbra

Portugal

Mobile phone: +351918842294

Teresa Almeida Santos ${ }^{2,3}$

anateresasantos.tas@gmail.com

Edf. S. Jerónimo

Praceta Prof. Mota Pinto

3000-075 Coimbra

Portugal

Cláudia Melo ${ }^{4}$

claudiasmelosilva@gmail.com

Rua do Colégio Novo

3000-115 Coimbra

Portugal

Ana Cristina Ribeiro Rama ${ }^{1,5}$

rama.acr@gmail.com

Rua Filipe Simões n 33

3000-186 Coimbra

Portugal

${ }^{1}$ Pharmacology Department, Faculty of Pharmacy of the University of Coimbra, Coimbra, Portugal.

${ }^{2}$ Centre for Fertility Preservation, Human Reproduction Department, Coimbra Hospital and University Centre (CHUC), EPE, Coimbra, Portugal.

${ }^{3}$ Faculty of Medicine of the University of Coimbra, Coimbra, Portugal.

${ }^{4}$ Faculty of Psychology and Educational Sciences of the University of Coimbra, Coimbra, Portugal.

${ }^{5}$ Centre for 20th Century Interdisciplinary Studies CEIS20. University of Coimbra, Coimbra, Portugal.

Keywords: infertility; fertility preservation; oncofertility; information resources, decision support 


\section{Introduction}

Infertility is a potential adverse effect of antineoplastic cancer therapy. The degree of gonadal toxicity from chemotherapy is influenced by several factors, such as patient age, total dose administered and the nature of antineoplastic agents. ${ }^{1,2}$ The possibility of an early diagnosis and considerable advances in cancer treatment, along with a rising incidence of cancer in teenagers and young adults, has led to an increase in the number of cancer survivors of reproductive age. In addition to facing the consequences of the disease, these patients will have to address the consequences of cancer treatments for their fertility. ${ }^{3}$ It is recognized that future fertility is an important issue for these patients; ${ }^{4}$ therefore, shared decisions concerning fertility preservation (FP) must occur at the time of diagnosis.

In this context, oncofertility, a term coined in 2006 by Teresa Woodruff, has recently emerged as a multidisciplinary field with the purpose of fulfilling the needs of cancer patients regarding their reproductive potential. ${ }^{5}$ Several professional organizations in the field of oncology have published recommendations regarding FP, advising health professionals to discuss infertility risks and FP options with all cancer patients of reproductive age. ${ }^{6,7}$ However, a number of published studies indicate that not every oncologist is following these orientations and that a considerable proportion of cancer patients is still not informed about the risks and possibilities regarding FP. ${ }^{8-13}$ Moreover, surveys of reproductive-age cancer patients and survivors disclose gaps in the information received about the opportunity of preserving fertility, the techniques available or the possibility of consultation with a reproductive medicine specialist. ${ }^{14-17}$ Decisions regarding FP, especially for female cancer patients, are complex and preference-sensitive, i.e., they need to consider patients' values for benefits and harms 
across options. ${ }^{18}$ All options come with risks and success rates and decisions concerning FP often have to be made in a short time frame, along with other treatment decisions and in a period of a great emotional distress. Several patient-related factors contribute to a quality decision-making process, including patients' values and attitudes, support from family and friends and the acquisition of information. ${ }^{19,20}$ Information resources conceived to support decisions in healthcare such as decision aids ${ }^{21,22}$ or decision trees ${ }^{23}$ provide a more clear understanding of the available options, facilitate discussions and increase patients' and professionals' involvement in the decisionmaking process.

In the specific setting of infertility risk in cancer patients, the access to specialized information concerning FP improved patients' knowledge of the available options ${ }^{24}$ and reduced decisional conflicts. $^{25}$

In Portugal, oncofertility is of increasing importance in the context of quality of life in cancer survival. Recently, several Portuguese scientific societies, including the Sociedade Portuguesa de Medicina da Reprodução (Portuguese Society for Reproductive Medicine, SPMR) and the Sociedade Portuguesa de Oncologia (Portuguese Oncology Society, SPO), in cooperation with the national hematology and andrology professional societies, published and endorsed the "Portuguese Recommendations for Preserving the Reproductive Potential of Cancer Patients". ${ }^{26}$ This document was the final outcome of the $1^{\text {st }}$ and $2^{\text {nd }}$ Portuguese Oncofertility Meetings in 2015 and 2016. The Portuguese Centro de Preservação da Fertilidade (Centre for Fertility Preservation, CFP) of Coimbra Hospital and University Centre (CHUC), EPE, was a leader in this process and has been working actively since 2012 to promote local and national awareness of oncofertility. In cooperation with the Liga Portuguesa Contra o Cancro (Portuguese League Against Cancer, LPCC), a Portuguese nonprofit cancer 
patients organization, the CFP conducted a project to develop and disseminate oncofertility information resources, directed both to health professionals and cancer patients. Here, we report the results of the specific component of this information program, which aimed to produce information resources for cancer patients to promote their informed participation in decisions in the context of infertility risks and FP.

\section{Methods}

\subsection{Assessment of information needs}

A literature search on Medline, through PubMed, was conducted to identify primary quantitative studies evaluating cancer patients' information needs or gaps in knowledge concerning infertility risks and FP options. The search equation was built using the following MeSH terms: Patient Education as Topic; Consumer Health Information/methods; Health education; Antineoplastic Agents/adverse effects; Infertility, Female; Infertility, Male; Sperm Banks; Cryopreservation; Reproductive Techniques, Assisted; and Fertility Preservation. The eligible articles were retrieved, and their results were gathered and organized. Additionally, a questionnaire directed to cancer survivors that had been diagnosed in reproductive age was applied locally ${ }^{*}$.

These self-reported, anonymous questionnaires were distributed by clinicians in followup consultations at several clinical departments of CHUC, EPE. Demographic, reproductive and clinical information was requested. Participants were asked to rate, on a 5-point Likert scale (ranging from Not important to Extremely important), their selfperceived importance of discussing specific information topics regarding infertility risks and FP before cancer treatment initiation. An additional question queried patients on the

*This self-reported questionnaire was developed and administered in collaboration with Cláudia Melo, as the responsible researcher of a PhD project on Health Psychology about fertility preservation. 
usefulness of several information strategies (from Not useful to Extremely useful). The study received approval from the local ethical committee, and the questionnaire was previously tested in a small group of cancer survivors. Patients were informed of the objectives and methods of the study, and all participants signed written consent.

\subsection{Development of information resources}

The information resources were designed to target cancer patients of reproductive age (18 to 40 years) with a recent cancer diagnosis (any type of cancer) before treatment initiation. To include relevant, yet specific, information for each gender (for instance, about fertility markers), distinct resources were developed for male and female patients. Bearing in mind that the risk of infertility is not acknowledged by many cancer patients $^{27-31}$ and the complexity of the decision-making process regarding FP, particularly in women, two different types of written patient information resources were planned: 1) general information handouts with the aim of raising awareness of the effects of cancer and cancer treatments on fertility; 2) decision aids with the aim of supporting decisions in the context of FP.

With the purpose of producing quality written health information materials, searches were conducted in Medline, through PubMed, to find general guidance for writing health information for patients. For the specific production of the decision aids, the criteria included in the DISCERN instrument ${ }^{32}$ (http://www.discern.org.uk/index.php) were taken into account. DISCERN consists of 16 key questions intending to evaluate the reliability of the publication, the information provided about treatment choices and its overall quality. This tool was designed to help users of consumer health information judge the quality of written information about treatment choices but can also be used as a checklist for authors and producers of written consumer health information. 
Published evidence on infertility risks and FP options in cancer patients was identified and the most current evidence-based knowledge on clinical indications, time requisites, success rates, risks and advantages/disadvantages of each FP technique was gathered.

\subsection{Evaluation of information resources Readability}

Readability is a measure of the facility with which a text is read, according to the length of words and sentences. Preliminary versions of the information resources were tested for readability using the Fernandez-Huerta index, a modified version of the Flesch Reading Ease score for the Spanish language. ${ }^{33}$ In the Flesch Reading Ease score, the results range from 0 (the worst level, very difficult to read) to 100 (the best readability level). Usually, a reading ease of 60-70 is considered standard (Table 1). ${ }^{34}$

The number of words and syllables was estimated using the software TextMeter, an application of text statistics for the Portuguese language. After the first readability results, improvements were made by using alternative, shorter words and building less complex sentences.

\section{Pre-test}

The first drafts of both the general information handouts and the decision aids were provided, along with an evaluation form, to reproductive-age cancer patients and survivors by oncologists and psychologists in fertility preservation and follow up consultations. They were also evaluated by a variety of healthcare professionals with direct or indirect involvement in the care of reproductive-age cancer patients (Table 2). These groups evaluated the content, language and layout of both information resources. Additionally, the ability of the decision aids to support shared decisions was assessed by 
asking if the different options were presented in a balanced way; if the information on each option was sufficient; and if the information would increase the knowledge about the options, help patients to discuss the options with their oncologist and promote their participation in decisions.

\section{Quality}

The quality of the information resources was assessed using EQIP (Ensuring Quality Information for Patients), a tool designed to measure the presentation quality of all types of written health care information, ${ }^{35}$ and the above-mentioned DISCERN instrument. $^{32}$

A flow diagram showing the sequence of steps in the development process can be seen in Figure 1.

\section{Results}

\subsection{Information needs}

In accordance with the defined eligibility criteria, ten published articles were selected and analyzed. ${ }^{27-31 ; 36-40}$ Data on methods and results on reported patient information needs or gaps in knowledge were collected from each individual article and are presented in Table 3.

In relation to the identification of local information needs, a sample of 31 cancer survivors answered and returned the questionnaire. It was not possible to calculate the response rate, as the total number of questionnaires distributed to patients by clinicians is not known. The mean age $( \pm \mathrm{SD})$ of the participants was of 34.4 years $( \pm 6.5)$, corresponding to a mean age of 26.6 years $( \pm 7.5)$ at diagnosis. Most participants were 
females $(n=27)$, and the most frequent cancer diagnoses were lymphoma $(n=9)$, breast cancer $(n=8)$ and osteosarcoma $(n=8)$. The majority of survivors $(n=23)$ had been treated with systemic chemotherapy. Almost one third $(n=10)$ reported effects of cancer treatments on fertility, and 15 answered that they did not know or were unsure of those effects. Two patients used a fertility preservation technique before treatment initiation, and three patients had children after cancer treatment. Table 4 presents the information topics included in the questionnaire. All topics were rated as Extremely important to be discussed or Very important to be discussed by a significant majority of participants.

Concerning the strategies that are useful to inform cancer patients on these topics, consultation with a reproductive medicine specialist and the supply of information through written information resources or the Internet were the most valued.

\subsection{Information resources}

The contents of the information resources were developed with our previously mentioned purposes in mind (section 2.2) and the information needs most frequently identified in the international literature and/or reported by the local sample of survivors. General criteria for writing health information for patients were collected from several published guidance documents ${ }^{41-42}$ and organized according to the following themes: content (e.g., clearly defined aim), language (e.g., avoid paternalism and value judgements, use active voice, avoid technical terms), organization (e.g., use bullets and write short, single idea paragraphs), layout and graphics (e.g., avoid uppercase and italic, align text to the left), illustrations (e.g., use only to improve understanding) and learning and motivation (include interactive materials). These criteria supported the process of writing and organizing the information content. 
In the general handouts, the information was organized in the format of Questions \& Answers as a form of dividing text and making it more attractive to read. ${ }^{42}$ In the decision aids, after a brief introduction discussing the relevance of shared decisionmaking regarding FP, contents were structured according to the two main decision points: 1) the decision to use or not use a FP technique; 2) when applicable, the decision of which FP technique to choose. In each decision point, the positive and negative aspects of each option were presented. Moreover, in the second decision point, detailed information on the procedures and target populations for each FP technique was included. A third section was designed with a set of three questions \& answers regarding general issues such as costs, maximum length of cryopreservation and fate of the non-used cryopreserved cells/tissues. Interactive components to increase learning and motivation (i.e., a box that patients can use to write questions and a small knowledge quiz at the end) were developed for all information resources. In the final section, other relevant sources of information were presented, including the address of the CFP's website and contact numbers of national telephone helplines on cancer and oncofertility.

Table 5 and Table 6 display images of the front page and briefly outline the contents included in the handouts and decision aids, respectively. As the local sample of survivors reported that provision of information through the Internet would also be a useful strategy, the information contents were also adapted to be digitally displayed on the CFP's website.

\subsubsection{Evaluation of the information resources}

Readability 
The final versions of the handouts informing of the possible effects of cancer (and cancer treatments) on male and female fertility were rated by the Fernandez-Huerta readability index as fairly difficult (score of 51). Readability of the decision aids to support FP decisions was classified as difficult, with scores of 46 for the male and 49 for the female decision aids.

Pre-test

In general, both cancer patients and healthcare professionals rated the information resources as easy to read, with contents that are relevant, complete and well organized. Only a few minor changes were necessary, mainly of language and sentence structure. Additionally, decision aids were considered by all participants as useful for shared decision-making and clinical practice.

Quality assessment

All information resources scored high on presentation quality, with EQUIP scores varying between 77 and $89 \%$. Consistent with the recommendations from this tool, the resources produced are "ready for distribution and should be reviewed in two to three years". According to the criteria from the DISCERN instrument, the overall quality of the two decision aids developed was high (4 or 5 scores in all questions). This rating means that the information materials "are useful and appropriate sources of information about treatment choices and have the ability to support the patient's decisions".

\subsubsection{Publication and dissemination}

The handouts informing of cancer and cancer treatment effects on male and female fertility were published in 2015 by the LPCC, which is also circulating these resources through its campaigns and website. With the collaboration of the Ordem dos Farmacêuticos - Secção Regional de Coimbra (Portuguese Pharmaceutical Society Center Regional Section; SRC-OF), the handouts were also distributed to pharmacies all 
over the country, in order to reach the population in a larger scale. More recently, the LPCC has also published the decision aids that are being distributed to oncologists and other cancer care clinicians, reproductive medicine specialists and fertility preservation centers, with the cooperation of SPMR and SPO.

Furthermore, all the produced information content is available, in Portuguese, on the website of the Centre for Fertility Preservation of CHUC, EPE (www.centropreservacaofertilidade.pt).

\section{Discussion}

We believe that our systematic method for the provision of patient informationassessing information needs, providing information to meet those needs, pre-testing the information resources with the target population and assessing their quality with validated instruments - is a sound approach to facilitate decision-making among cancer patients in the context of infertility risks and FP options. Moreover, the use of quality decision aids that describe the path of patient decision-making and the consequences of each separate decision will lead patients to more informed clinical judgments. ${ }^{43-44}$ Our results indicate that the developed resources are relevant, reliable, and useful and have the ability to support shared decisions in the context of FP. They were positively evaluated by cancer patients, cancer survivors and health professionals working in the cancer and reproduction settings and achieved high quality scores according to the instruments EQIP and DISCERN. Concerning readability, the general handouts and the decision aids were scored as fairly difficult and difficult to read, respectively, which means they are suitable for readers with at least high-school grade levels. These low levels of readability are potential barriers for their ability to inform patients and support shared decisions so it is important to further assess the resources in real contexts of decision. Nevertheless, readability scores must always be interpreted with caution. They 
assume that longer words and sentences are harder to read and do not measure comprehension or indicate if the words are familiar to the reader. For example, some recurrently used Portuguese words in the setting of reproduction and fertility preservation, such as "espermatozoide", "fertilidade" and "congelação", are common and easily understandable words, yet they negatively influence the readability scores because of their many syllables. In the specific case of decision aids (scored as difficult to read), it will be important to use direct measures of comprehension, such as their ability to promote shared decision-making and to reduce decisional conflict.

The developed resources were designed to target adult patients in reproductive age faced with a diagnosis of any type of cancer. Accordingly, no cancer-specific information about infertility risks or fertility preservation options was included. Furthermore, they may not be suitable for children or adolescents with cancer, since younger patients may have distinct needs and preferences regarding the provision of information. ${ }^{45-46}$ It is also a fact that some of the identified information needs remained unmet. Some topics were beyond the scope of our resources (for instance, the effects of cancer in sexual function, contraception in cancer patients or information about infertility treatments), while for others, the information would be influenced by the specific type of cancer (such as the risk of genetic transmission of cancer to offspring and the risk of cancer recurrence due to pregnancy). Clearly, these are subjects to include in upcoming information resources. Other limitations of our study are related to the methods for the assessment of information needs. Due to time constraints, qualitative studies were not included in the literature search, and the locally applied questionnaire had a small number of participants.

We wish to highlight the multidisciplinary context in which this project has been carried out, involving cancer patients and survivors, a cancer patients' organization (LPCC), 
oncologists and other cancer care professionals and professional and scientific societies in the fields of oncology and reproductive medicine. We hope this intense cooperation will contribute to a wider dissemination of the developed information materials to the various stakeholders in the process of cancer care and to a more effective clinical implementation. Additionally, it is important to note that information resources directed to oncologists were also developed in the context of this program, including a main booklet with comprehensive contents, tailored to the needs of clinicians working with cancer patients, and a brochure with summarized contents intended for other cancer care professionals and primary care professionals. $^{47}$

The developed resources are already available to the Portuguese population and to cancer patients in several institutions all over the country. Our next step will be to evaluate the resources with cancer patients using relevant measures such as acceptability, knowledge, decision conflict or self-efficacy.

\section{Conclusion}

The need to inform cancer patients in an effective and timely manner of their infertility risks and the possibility and options of FP is a recognized relevant issue in the context of quality of life in cancer survival. Through a systematic approach and establishing a multidisciplinary collaboration, information resources directed to cancer patients' needs were successfully developed and disseminated and will contribute to timely, shared and informed clinical decisions in the context of FP.

\section{Acknowledgements}

This work was supported by a research grant from the Liga Portuguesa contra o Cancro (Grant LPCC/Celgene 2012). 
The authors wish to thank to Professor Paula Fresco, PharmD, PhD, for her important contributions to revising the article's spelling and grammar.

\section{Author Disclosure Statement}

No competing financial interests exist.

\section{References}

1. Knopman JM, Papadopoulos EB, Grifo JA, Fino ME, et al. Surviving childhood and reproductive-age malignancy: effects on fertility and future parenthood. Lancet Oncol. $2010 ; 11: 490-8$.

2. Donnez J, Dolmans MM. Preservation of fertility in females with haematological malignancies. Br J Haematol. 2011;154:175-84.

3. Schover LR. Sexuality and Fertility after Cancer. Hematol 2005;1:523-7.

4. Deshpande NA, Braun IM, Meyer FL. Impact of fertility preservation counseling and treatment on psychological outcomes among women with cancer: A systematic review. Cancer. 2015;121:3938-47.

5. Woodruff TK. The Oncofertility Consortium - addressing fertility in young people with cancer. Nat Rev Clin Oncol. 2010;7:466-75.

6. Lee SJ, Schover LR, Partridge AH, Patrizio P, et al. American Society of Clinical Oncology. American Society of Clinical Oncology recommendations on fertility preservation in cancer patients. J Clin Oncol. 2006;24: 2917-31.

7. ESMO Guidelines Working Group. Cancer, pregnancy and fertility: ESMO Clinical Practice Guidelines for diagnosis, treatment and follow-up. Ann Oncol. 2013;24:vi16070. 
8. Quinn GP, Vadaparampil ST, Lee JH, Jacobsen PB, et al. Physician referral for fertility preservation in oncology patients: a national study of practice behaviors. J Clin Oncol. 2009; 27:5952-7.

9. Quinn GP, Vadaparampil ST, Gwede CK, Miree C, et al. Discussion of fertility preservation with newly diagnosed patients: oncologists' views. J Cancer Surviv. $2007 ; 1: 146-55$.

10. Shimizu C, Bando H, Kato T, Mizota Y, et al. Physicians' knowledge, attitude, and behavior regarding fertility issues for young breast cancer patients: a national survey for breast care specialists. Breast Cancer. 2013;20:230-40.

11. King JW, Davies MC, Roche N, Abraham JM, et al. Fertility preservation in women undergoing treatment for breast cancer in the UK: a questionnaire study. Oncologist. 2012;17:910-6.

12. Schover LR, Brey K, Lichtin A, Lipshultz LI, et al. Oncologists' attitudes and practices regarding banking sperm before cancer treatment. J Clin Oncol. 2002;20:18907.

13. Forman EJ, Anders CK, Behera MA. A nationwide survey of oncologists regarding treatment-related infertility and fertility preservation in female cancer patients. Fertil Steril. 2010;94:1652-6.

14. Wilkes S, Coulson S, Crosland A, Rubin G, et al. Experience of fertility preservation among younger people diagnosed with cancer. Hum Fertil (Camb). $2010 ; 13: 151-8$

15. Partridge AH, Gelber S, Peppercorn J, Sampson E, et al. Web-Based Survey of Fertility Issues in Young Women With Breast Cancer. J Clin Oncol. 22:4174-83. 
16. Peate M, Meiser B, Hickey M, Friedlander M. The fertility-related concerns, needs and preferences of younger women with breast cancer: a systematic review. Breast Cancer Res Treat. 2009;116:215-23.

17. Schover LR, Brey K, Lichtin A, Lipshultz LI, et al. Knowledge and Experience Regarding Cancer, Infertility, and Sperm Banking in Younger Male Survivors. J Clin Oncol. 2002;20:1880-9.

18. Balthazar U, Deal AM, Fritz MA, Kondapalli LA, et al. The current fertility preservation consultation model: are we adequately informing cancer patients of their options? Hum Reprod. 2012, 27:2413-9.

19. Michie S, Dormandy E, Marteau TM. The multi-dimensional measure of informed choice: a validation study. Patient Educ Couns. 2002;48:87-91.

20. Woolf SH, Chan EC, Harris R, Sheridan SL, et al. Promoting Informed Choice: transforming health care to dispense knowledge for decision making. Ann Intern Med. 2005; 143:293-300.

21. Stacey D, Samant R, Bennett C. Decision making in oncology: a review of patient decision aids to support patient participation. CA Cancer J Clin. 2008;58:293-304.

22. Stacey D, Bennett CL, Barry MJ, Col NF, et al. Decision aids to help people who are facing health treatment or screening decisions. Cochrane Database Syst Rev. 2011;10:CD001431.

23. Hunink MG. In search of tools to aid logical thinking and communicating about medical decision making. Med Decis Making. 2001;21:267-77.

24. Garvelink MM, ter Kuile MM, Stiggelbout AM, de Vries M. Values clarification in a decision aid about fertility preservation: does it add to information provision? BMC Med Inform Decis Mak. 2014;14:68. 
25. Peate M, Meiser B, Cheah BC, Saunders C, et al. Making hard choices easier: a prospective, multicentre study to assess the efficacy of a fertility-related decision aid in young women with early-stage breast cancer. Br J Cancer. 2012;106:1053-61.

26. Almeida Santos AT, Sousa G, Teixeira A, Cardoso P, et al. Recommendations for the preservation of reproductive potential in cancer patients. Rev Port Oncol. 2016; 2:524.

27. Armuand GM, Rodriguez-Wallberg KA, Wettergren L, Ahlgren J, et al. Sex Differences in Fertility-Related Information Received by Young Adult Cancer Survivors. J Clin Oncol. 2012;30:2147-53.

28. Jukkala AM, Azuero A, McNees P, Bates GW, et al. Self-assessed knowledge of treatment and fertility preservation in young women with breast cancer. Fertil Steril. 2010;94:2396-8.

29. Scanlon M, Blaes A, Geller M, Majhail NS, et al. Patient Satisfaction with Physician Discussions of Treatment Impact on Fertility, Menopause and Sexual Health among Pre-menopausal Women with Cancer. J Cancer. 2012;3:217-25.

30. Schover LR, Brey K, Lichtin A, Lipshultz LI, et al. Knowledge and Experience Regarding Cancer, Infertility, and Sperm Banking in Younger Male Survivors. J Clin Oncol. 2002;20:1880-9.

31. Zebrack B. Information and service needs for young adult cancer patients. Supp Care Cancer. 2009;17:349-57.

32. Charnock D, Shepperd S, Needham G, Gann R. DISCERN: an instrument for judging the quality of written consumer health information on treatment choices. J Epidemiol Comm Health. 1999;53:105-11.

33. Fernández-Huerta J. Medidas sencillas de lecturabilidad. Consigna. 1959;214:2933. 
34. Flesch R. How to Write Plain English. University of Canterbury Business School. Accessed October 7, 2017 from http://www.mang.canterbury.ac.nz/writing_guide/writing/flesch.shtml. 35. Moult B, Franck LS, Brady H. Ensuring Quality Information for Patients: development and preliminary validation of a new instrument to improve the quality of written health care information. Health Expect. 2004;7:165-75.

36. Balthazar U, Fritz, MA, Mersereau JE. Fertility preservation: a pilot study to assess previsit patient knowledge quantitatively. Fertil Steril. 2011;95:1913-6.

37. Balthazar U, Deal AM, Fritz MA, Kondapalli LM, et al. The current fertility preservation consultation model: are we adequately informing cancer patients of their options? Hum Reprod. 2012;27:2413-19.

38. Meneses K, McNees P, Azuero, A, Jukkala A. Development of the Fertility and Cancer Project: An Internet Approach to Help Young Cancer Survivors. Oncol Nurs Forum. 2010;37:191-7.

39. Peate M, Meiser B, Friedlander M, Zorbas H, et al. It's Now or Never: FertilityRelated Knowledge, Decision-Making Preferences, and Treatment Intentions in Young Women With Breast Cancer-An Australian Fertility Decision Aid Collaborative Group Study. J Clin Oncol. 2011;29:1670-7.

40. Thewes B, Meiser B, Taylor A, Phillips KA, et al. Fertility- and Menopause-Related Information Needs of Younger Women With a Diagnosis of Early Breast Cancer. J Clin Oncol. 2005;23:5155-65.

41. Hoffmann T, Worrall L. Designing effective written health education materials: Considerations for health professionals. Disab Rehabilit. 2004;26:1166-73. 
42. General guidance on writing information for patients. NHS Department of Health. In: NHS Toolkit for producing patient information. 2003. Accessed November, 2013 from: $\underline{\text { https://www.uea.ac.uk/documents/246046/0/Toolkit } \pm \text { for } \pm \text { producing } \pm \text { patient } \pm \text { information.pdf }}$ 43. Gardino SL, Jeruss JS, Woodruff TK. Using decision trees to enhance interdisciplinary team work: the case of oncofertility. J Assist Reprod Genet. 2010;27: $227-31$.

44. Aleem IS, Jalal H, Aleem IS, Sheikh AA, Bhandari M. Clinical decision analysis: incorporating the evidence with patient preferences. Patient Prefer Adherence. $2009 ; 3: 21-4$.

45. Murphy D, Sawczyn KK, Quinn GP. Using a patient-centered approach to develop a fertility preservation brochure for pediatric oncology patients: a pilot study. J Pediatr Adolesc Gynecol. 2012;25:114-21.

46. Wyns C, Collienne C, Shenfield F, et al. Fertility preservation in the male pediatric population: factors influencing the decision of parents and children. Hum Reprod. 2015 Sep;30(9):2022-30.

47. Silva C, Almeida-Santos AT, Melo C, Rama ACR. J Adolesc Young Adult Oncol. 2017;6:353-57. 
Table 1. Flesch Reading Ease scores and corresponding readability and school levels.

\begin{tabular}{|l|l|l|}
\hline $\begin{array}{l}\text { Flesch Reading } \\
\text { Ease score }\end{array}$ & $\begin{array}{l}\text { Readability } \\
\text { level }\end{array}$ & $\begin{array}{l}\text { School level } \\
\text { (Easy to read for...) }\end{array}$ \\
\hline $0-30$ & Very difficult & $\begin{array}{l}\text { College graduate } \\
\text { (University degree) }\end{array}$ \\
\hline $30-50$ & Difficult & $\begin{array}{l}\text { College } \\
\text { (University student) }\end{array}$ \\
\hline $50-60$ & Fairly difficult & $\begin{array}{l}10^{\text {th }}-12^{\text {th }} \text { grade } \\
\text { High school graduate }\end{array}$ \\
\hline $60-70$ & Standard & $8^{\text {th }}-9^{\text {th }}$ grade \\
\hline $70-80$ & Fairly easy & $7^{\text {th }}$ grade \\
\hline $80-90$ & Easy & $6^{\text {th }}$ grade \\
\hline $90-100$ & Very easy & $5^{\text {th }}$ grade \\
\hline
\end{tabular}


Table 2. Evaluation criteria and evaluation groups used to pre-test the information resources.

\begin{tabular}{|c|c|c|}
\hline & Evaluation criteria & Evaluation groups \\
\hline $\begin{array}{l}\text { General } \\
\text { information } \\
\text { handouts }\end{array}$ & $\begin{array}{l}\text { - Content (usefulness, } \\
\text { completeness, } \\
\text { organization) } \\
\text { - Language } \\
\text { - Layout (colors, titles, } \\
\text { highlights, fonts) }\end{array}$ & $\begin{array}{l}\text { Patients } \\
\text { - Female cancer patients }(\mathrm{n}=3) \\
\text { - Female cancer survivors }(\mathrm{n}=6) \\
\text { - Male cancer survivors ( } \mathrm{n}=3) \\
\text { Cancer care professionals } \\
\text { - Psychologists ( } \mathrm{n}=1) \\
\text { - Hospital pharmacists ( } \mathrm{n}=2) \\
\text { - Oncologists ( } \mathrm{n}=2) \\
\text { - Hematologists ( } \mathrm{n}=1) \\
\text { - Gynecologists ( } \mathrm{n}=2) \\
\text { Human reproduction professionals } \\
\text { - Reproductive medicine specialists } \\
\text { (n=2) } \\
\text { - Nurses (n=2) } \\
\text { Other healthcare professionals } \\
\text { - Community pharmacists (n=2) }\end{array}$ \\
\hline Decision aids & $\begin{array}{l}\text { - Content (usefulness, } \\
\text { completeness, } \\
\text { organization) } \\
\text { - Language } \\
\text { - Layout (colors, titles, } \\
\text { highlights, fonts) } \\
\text { - Ability to support } \\
\text { decisions } \\
\text { - Usefulness for clinical } \\
\text { practice (health } \\
\text { professionals) }\end{array}$ & $\begin{array}{l}\text { Patients } \\
\text { - Female cancer patients }(\mathrm{n}=3) \\
\text { - Female cancer survivors }(\mathrm{n}=6) \\
\text { - Male cancer survivors }(\mathrm{n}=3) \\
\text { Cancer care professionals } \\
\text { - Psychologists ( } \mathrm{n}=1) \\
\text { - Hospital pharmacists }(\mathrm{n}=2) \\
\text { - Oncologists }(\mathrm{n}=2) \\
\text { - Hematologists }(\mathrm{n}=1) \\
\text { - Gynecologists ( } \mathrm{n}=2) \\
\text { Reproductive health professionals } \\
\text { - Reproductive medicine specialists } \\
\text { (n=2) } \\
\text { - Embryologist (n=1) } \\
\text { - Nurses (n=2) }\end{array}$ \\
\hline
\end{tabular}


Table 3. Data on studies identifying cancer patients' information needs or gaps in knowledge concerning infertility risks and FP options.

\begin{tabular}{|c|c|c|c|}
\hline Reference & Title & $\begin{array}{l}\text { Methods } \\
\text { (sample) }\end{array}$ & $\begin{array}{l}\text { Information needs / gaps in } \\
\text { knowledge identified }\end{array}$ \\
\hline $\begin{array}{l}\text { Armuand GM. } \\
\text { J Clin Oncol } \\
2012 \text {; } \\
30: 2147-53^{27}\end{array}$ & $\begin{array}{l}\text { Sex differences in } \\
\text { fertility-related } \\
\text { information received } \\
\text { by young adult } \\
\text { cancer survivors }\end{array}$ & $\begin{array}{l}\text { Postal questionnaire } \\
\text { sent to cancer } \\
\text { survivors identified } \\
\text { in population-based } \\
\text { registers in Sweden } \\
(n=484)\end{array}$ & $\begin{array}{l}\text { - Effects of cancer treatments on } \\
\text { fertility } \\
\text { - Effects of cancer treatments on } \\
\text { future children }\end{array}$ \\
\hline $\begin{array}{l}\text { Balthazar U. } \\
\text { Fertil Steril } \\
\text { 2011; } \\
95: 1913-6^{36}\end{array}$ & $\begin{array}{l}\text { Fertility preservation: } \\
\text { a pilot study to assess } \\
\text { previsit patient } \\
\text { knowledge } \\
\text { quantitatively }\end{array}$ & $\begin{array}{l}\text { Consecutive new } \\
\text { FP patients seen at } \\
\text { the University of } \\
\text { North Carolina } \\
\text { completed a pre- } \\
\text { consultation } \\
\text { questionnaire } \\
(\mathrm{n}=41)\end{array}$ & $\begin{array}{l}\text { - Success rates of FP techniques } \\
\text { - Effect of FP in cancer recurrence } \\
\text { - Effects of cancer treatments on } \\
\text { future children } \\
\text { - Costs of FP } \\
\text { - FP options before and after cancer } \\
\text { treatment } \\
\text { - Established versus experimental FP } \\
\text { options }\end{array}$ \\
\hline $\begin{array}{l}\text { Balthazar U. } \\
\text { Hum Rep } \\
2012 ; \\
27: 2413-19^{37}\end{array}$ & $\begin{array}{l}\text { The current fertility } \\
\text { preservation } \\
\text { consultation model: } \\
\text { are we adequately } \\
\text { informing cancer } \\
\text { patients of their } \\
\text { options? }\end{array}$ & $\begin{array}{l}\text { Web-based survey } \\
\text { at academic IVF } \\
\text { centers, including } \\
\text { women aged 18-43 } \\
\text { years seen for } \\
\text { comprehensive FP } \\
\text { consultation }\end{array}$ & $\begin{array}{l}\text { - Time requirements for FP } \\
\text { - Pregnancy rates after FP } \\
\text { - Effect of FP on cancer recurrence } \\
\text { - Age as a very important factor for } \\
\text { FP success } \\
\text { - Maximum time of embryo/oocyte } \\
\text { cryopreservation } \\
\text { - Effects of oophorectomy in future } \\
\text { fertility }\end{array}$ \\
\hline $\begin{array}{l}\text { Jukkala AM, } \\
\text { Fertil Steril } \\
2010 ; \\
94: 2396-8^{28}\end{array}$ & $\begin{array}{l}\text { Self-assessed } \\
\text { knowledge of } \\
\text { treatment and fertility } \\
\text { preservation in young } \\
\text { women with breast } \\
\text { cancer }\end{array}$ & $\begin{array}{l}\text { Online assessment } \\
\text { of knowledge in } \\
\text { women ( } 18 \text { to } 50 \\
\text { years) with history } \\
\text { of breast cancer } \\
(\mathrm{n}=106)\end{array}$ & $\begin{array}{l}\text { - Effects of cancer and cancer } \\
\text { treatments on fertility } \\
\text { - Infertility treatments } \\
\text { - FP options }\end{array}$ \\
\hline $\begin{array}{l}\text { Karen M. } \\
\text { Oncol Nurs } \\
\text { Forum 2010; } \\
37: 191-7^{38}\end{array}$ & $\begin{array}{l}\text { Development of the } \\
\text { Fertility and Cancer } \\
\text { Project: An Internet } \\
\text { Approach to Help } \\
\text { Young Cancer } \\
\text { Survivors }\end{array}$ & $\begin{array}{l}\text { Internet survey to } \\
\text { assess fertility } \\
\text { knowledge of } \\
\text { young survivors of } \\
\text { breast cancer from } \\
\text { eight } \\
\text { countries }(n=106)\end{array}$ & $\begin{array}{l}\text { - Infertility treatments } \\
\text { - FP options }\end{array}$ \\
\hline $\begin{array}{l}\text { Peate M. J } \\
\text { Clin Oncol } \\
\text { 2011; } \\
\text { 29:1670-7 } 7^{39}\end{array}$ & $\begin{array}{l}\text { It's Now or Never: } \\
\text { Fertility-Related } \\
\text { Knowledge, } \\
\text { Decision-Making } \\
\text { Preferences, and } \\
\text { Treatment Intentions } \\
\text { in Young Women } \\
\text { with Breast Cancer- } \\
\text { An Australian } \\
\text { Fertility Decision Aid } \\
\text { Collaborative Group } \\
\text { Study }\end{array}$ & $\begin{array}{l}\text { Survey of women } \\
\text { diagnosed with } \\
\text { early breast cancer } \\
\text { and reporting } \\
\text { incomplete families } \\
(\mathrm{n}=111)\end{array}$ & $\begin{array}{l}\text { - Effects of hormonal therapy on } \\
\text { fertility } \\
\text { - Established versus experimental FP } \\
\text { options } \\
\text { - Effect of pregnancy on cancer } \\
\text { recurrence } \\
\text { - Success rates of FP techniques } \\
\text { - Time requirements for FP }\end{array}$ \\
\hline
\end{tabular}


Patient Satisfaction with Physician

Discussions of

Scanlon M. J Treatment Impact on Cancer 2012; Fertility, Menopause 3: $217-25^{29}$ and Sexual Health among Premenopausal Women with Cancer

Schover LR. J
Clin Oncol
$2002 ; 20: 1880-$
$9^{30}$

Knowledge and

Experience Regarding Cancer, Infertility, and Sperm Banking in Younger Male Survivors
Questionnaire applied to premenopausal women with cancer diagnosis in 2 time points (at enrollment and at 1year follow-up) $(n=104)$ to men with a new diagnosis of cancer at $14-40$ years of age $(n=201)$
- Effects of cancer and cancer treatments on sperm quality

- Infertility risk in boys versus girls

- Amount of sperm needed for infertility treatments

- Risk of cancer in future children

- Contraception

- Possibility of pregnancy after cancer treatment

Fertility- and Mail questionnaire Thewes B. J Menopause-Related sent to women with Clin Oncol Information Needs of a diagnosis of early2005; $23: 5155-65^{40}$

Younger Women stage breast cancer with a Diagnosis of aged $\leq 40$ years at Early Breast Cancer diagnosis $(\mathrm{n}=228)$

- Effects of pregnancy on cancer recurrence

- Risks/benefits of having children after cancer

- Effects of cancer treatments on future children

- Statistics on infertility risks

- Onset of infertility after cancer treatments

\begin{tabular}{llll}
\hline & & Online survey of & \\
Zebrack B. & Information and & young adults aged & \\
Supp Care & service needs for & $\begin{array}{l}18-40 \text { years and } \\
\text { diagnosed with }\end{array}$ & $\bullet$ Infertility risks \\
Cancer & young & cancer between the & $\bullet$ Infertility treatments/services \\
$2008 ; 16: 1353-$ & adult cancer patients & $\begin{array}{l}\text { ages of 15-35 } \\
60^{31}\end{array}$ & \\
& & $(\mathrm{n}=217)$ \\
\hline
\end{tabular}


Table 4. List of information topics ordered according to the number of cancer survivors rating them as Extremely important or Very important to discuss before treatment initiation $(n=31)$.

\begin{tabular}{|c|c|c|c|}
\hline Information topics & $\begin{array}{l}\text { Extremely } \\
\text { important to } \\
\text { discuss } \\
\text { (n) }\end{array}$ & $\begin{array}{c}\text { Very } \\
\text { important } \\
\text { to discuss } \\
\text { (n) }\end{array}$ & $\begin{array}{l}\text { Total } \\
\text { (n) }\end{array}$ \\
\hline $\begin{array}{l}\text { Risks of effects of cancer treatments for future } \\
\text { reproductive function/fertility }\end{array}$ & 17 & 11 & 28 \\
\hline $\begin{array}{l}\text { Risk of malformation in the offspring due to } \\
\text { cancer treatments }\end{array}$ & 23 & 5 & 28 \\
\hline Possibility of having children after cancer & 18 & 10 & 28 \\
\hline $\begin{array}{l}\text { Type of effects of cancer treatments on } \\
\text { reproductive function/fertility }\end{array}$ & 20 & 8 & 28 \\
\hline $\begin{array}{l}\text { In women, risk of cancer recurrence due to } \\
\text { pregnancy }\end{array}$ & 21 & 6 & 27 \\
\hline $\begin{array}{l}\text { Risk of genetic transmission of cancer to the } \\
\text { offspring }\end{array}$ & 19 & 8 & 27 \\
\hline FP options before and during treatments & 15 & 12 & 27 \\
\hline Available FP techniques & 13 & 14 & 27 \\
\hline Advantages of FP techniques & 14 & 13 & 27 \\
\hline Disadvantages of FP techniques & 16 & 11 & 27 \\
\hline Interference of FP in cancer treatment & 16 & 11 & 27 \\
\hline $\begin{array}{l}\text { Duration of effects of cancer treatments on } \\
\text { reproductive function/fertility }\end{array}$ & 18 & 8 & 26 \\
\hline Success rates & 14 & 12 & 26 \\
\hline Availability of FP specialists & 14 & 12 & 26 \\
\hline $\begin{array}{l}\text { In women, risk of early menopause due to cancer } \\
\text { treatments }\end{array}$ & 17 & 7 & 24 \\
\hline Costs & 15 & 9 & 24 \\
\hline How long the gametes can stay cryopreserved & 15 & 9 & 24 \\
\hline
\end{tabular}


Table 5. Front pages, titles and information contents of the handouts informing of the possible effects of cancer (and cancer treatments) on male and female fertility.

\section{Front-page image}

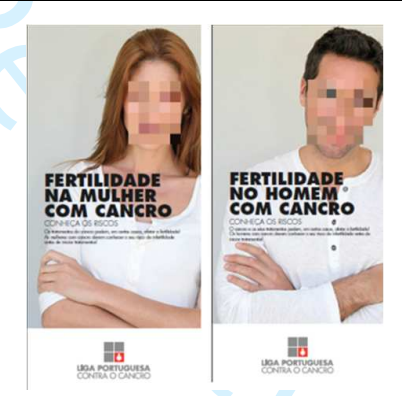

Title

Questions \& Answers

- How to know if a woman/man is fertile?

- Is it possible to have children after cancer?

- When should the discussion with the doctor about the possible effects of cancer Fertility in in fertility occur?

Men/Women - How to know if fertility can be affected?

with Cancer:

Know the

Risks
- How do cancer treatments affect fertility? Surgery, Radiotherapy, Chemotherapy... 
Table 6. Front pages, titles and information contents of the decision aids for male and female cancer patients to support shared decision-making about FP.

\begin{tabular}{|c|c|c|}
\hline Front-page image & Title & Information contents \\
\hline 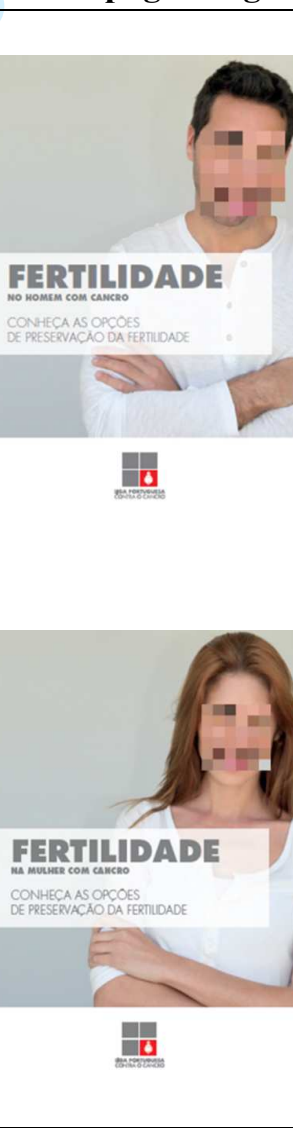 & $\begin{array}{l}\text { Fertility in Men } \\
\text { with Cancer: } \\
\text { Know the } \\
\text { Fertility } \\
\text { Preservation } \\
\text { Options }\end{array}$ & $\begin{array}{l}\text { - What is "fertility preservation"? } \\
\text { - What are the available options? } \\
\text { - Comprehensive information on procedures, } \\
\text { indications, success rates and risks of each } \\
\text { FP technique; } \\
\text { - Answers to frequent questions regarding costs, } \\
\text { conservation and disposal of the cryopreserved } \\
\text { material; } \\
\text { - Other sources of information: websites, } \\
\text { telephone helplines; } \\
\text { - Interactive components: box to write questions; } \\
\text { knowledge quiz. } \\
\text { - What is "fertility preservation"? } \\
\text { - What are the available options? } \\
\text { - } 1^{\text {st }} \text { decision - to preserve or not fertility - } \\
\text { positive and negative aspects of each option } \\
\text { - } 2^{\text {nd }} \text { decision - which FP technique to choose } \\
\text { - comprehensive information on procedures, } \\
\text { indications, success rates and risks of each } \\
\text { FP technique; } \\
\text { - Answers to general questions regarding costs, } \\
\text { maintenance and disposal of non-used } \\
\text { cryopreserved material; } \\
\text { - Other sources of information: websites, } \\
\text { telephone helplines; } \\
\text { - Interactive components: box to write questions; } \\
\text { knowledge quiz. }\end{array}$ \\
\hline
\end{tabular}


Figure 1. Flow diagram showing the sequential steps in the development of information resources.

Figure 1. Flow diagram showing the sequential steps in the development of information resources.

$368 \times 250 \mathrm{~mm}(96 \times 96$ DPI $)$ 